\title{
Disparitas Pendapatan di Jawa Tengah
}

\author{
Muliasari Pinilih* \\ Universitas Amikom Purwokerto \\ Purwokerto, Jawa Tengah, Indonesia. \\ Email: mpinilih@amikompurwokerto.ac.id
}

\begin{abstract}
Abstrak
Disparitas pendapatan masih menjadi salah satu perhatian bagi pemerintah daerah Jawa Tengah. Ketidakmerataan pendapatan dapat disebabkan oleh beberapa faktor. Maka dari itu, penelitian ini memiliki tujuan untuk menganalisis pengaruh pertumbuhan ekonomi, investasi yang akan dibagi menjadi PMDN (Penanaman Modal Dalam Negeri) dan PMA (Penanaman Modal Asing), inflasi, angkatan kerja, pertumbuhan penduduk dan kontribusi sektor terhadap disparitas pendapatan di Jawa Tengah pada periode 2014-2019. Data-data seperti PDRB, PDMN, PMA, inflasi, angkatan kerja, pertumbuhan penduduk dan kontribusi sektor didapatkan dari BPS Provinsi Jawa Tengah dan akan dianalisis dengan menggunakan analisa regresi, uji t dan uji F. Hasil yang didapatkan menunjukkan hanya PMDN dan kontribusi sektor yang memiliki kemampuan secara parsial untuk mempengaruhi disparitas pendapatan sementara pertumbuhan ekonomi, PMA, inflasi, angkatan kerja dan pertumbuhan penduduk tercatat tidak mampu menpengaruhi secara parsial disparitas distribusi pendapatan. Jika diuji secara simultan, pertumbuhan ekonomi, PMDN, PMA, inflasi, angkatan kerja, pertumbuhan penduduk dan kontribusi sektor tercatat mampu memberikan pengaruh terhadap disparitas distribusi pendapatan.
\end{abstract}

Kata Kunci: Disparitas, kontribusi sektor, PMA, PMDN

\begin{abstract}
The income disparity is still a concern for the Central Java regional government. Several factors can cause inequality of income. Therefore, this study aims to analyze the effect of economic growth, an investment that will be divided into PMDN (Domestic Investment) and PMA (Foreign Investment), inflation, labor force, population growth, and sector contribution to income inequality in Central Java in the 2014-2019 period. The data like PDRB, PMDN, PMA, inflation, labor force, population growth, and sector contribution is obtained from the Central Java Province BPS and analyzed using regression analysis, $t$-test, and F-test. The results obtained indicate that only PMDN (Domestic Investment) and sector contributions partially influence income disparity. Simultaneously, economic growth, PMA (Foreign Investment), inflation, labor force, and population growth are recorded as not being able to affect a difference in income distribution partially.
\end{abstract}

Keywords: Disparity, sector contribution, PMA, PMDN

\section{Pendahuluan}

Pembahasan mengenai pertumbuhan dan pembangunan ekonomi menjadi pokok permasalahan yang cukup krusial di suatu negara. Negara bertugas untuk meningkatkan pembangunan ekonomi agar kemakmuran masyarakat dapat tercapai, namun proses pembangunan ekonomi akan menimbulkan dilema bagi suatu negara. Sasaran dalam strategi dasar akan terfokus pada dua aspek, yaitu prioritas pada pertumbuhan ekonomi yang tinggi atau hasil pembangunan yang merata untuk masyarakat (Arsyad, 2010). Namun, dalam kenyataannya menyelaraskan keduanya tidaklah mudah. Apabila ingin mencapai pemerataan maka pencapaian pertumbuhan yang tinggi akan memerlukan waktu yang lama dan apabila pertumbuhan tinggi yang menjadi tujuan maka jurang kesenjangan semakin melebar (Permana, 2016).

Permasalahan ketimpangan dalam distribusi pendapatan dapat diakibatkan oleh beberapa variabel. Salah satu hal yang memunculkan ketimpangan distribusi pendapatan adalah keadaan masing-masing daerah yang yang memiliki karakteristik, topografi, dan potensi yang berbeda (Aminah, 2017). Masalah ketimpangan distribusi pendapatan ini juga terjadi di Provinsi Jawa Tengah. Berdasarkan data BPS, pada 2018 terlihat bahwa kabupaten/kota yang paling besar memiliki kontribusi adalah kota Semarang dengan nilai kontribusi terhadap PDRB Jawa Tengah sebesar 13,84 persen dan kontribusi paling kecil adalah Kota Magelang dengan kontribusi sebesar 0,65 persen. Kondisi ini sudah menunjukkan perbedaan kondisi antardaerah yang cukup signifikan. Lihat Gambar 1.

\footnotetext{
${ }^{*}$ Corresponding Author
} 


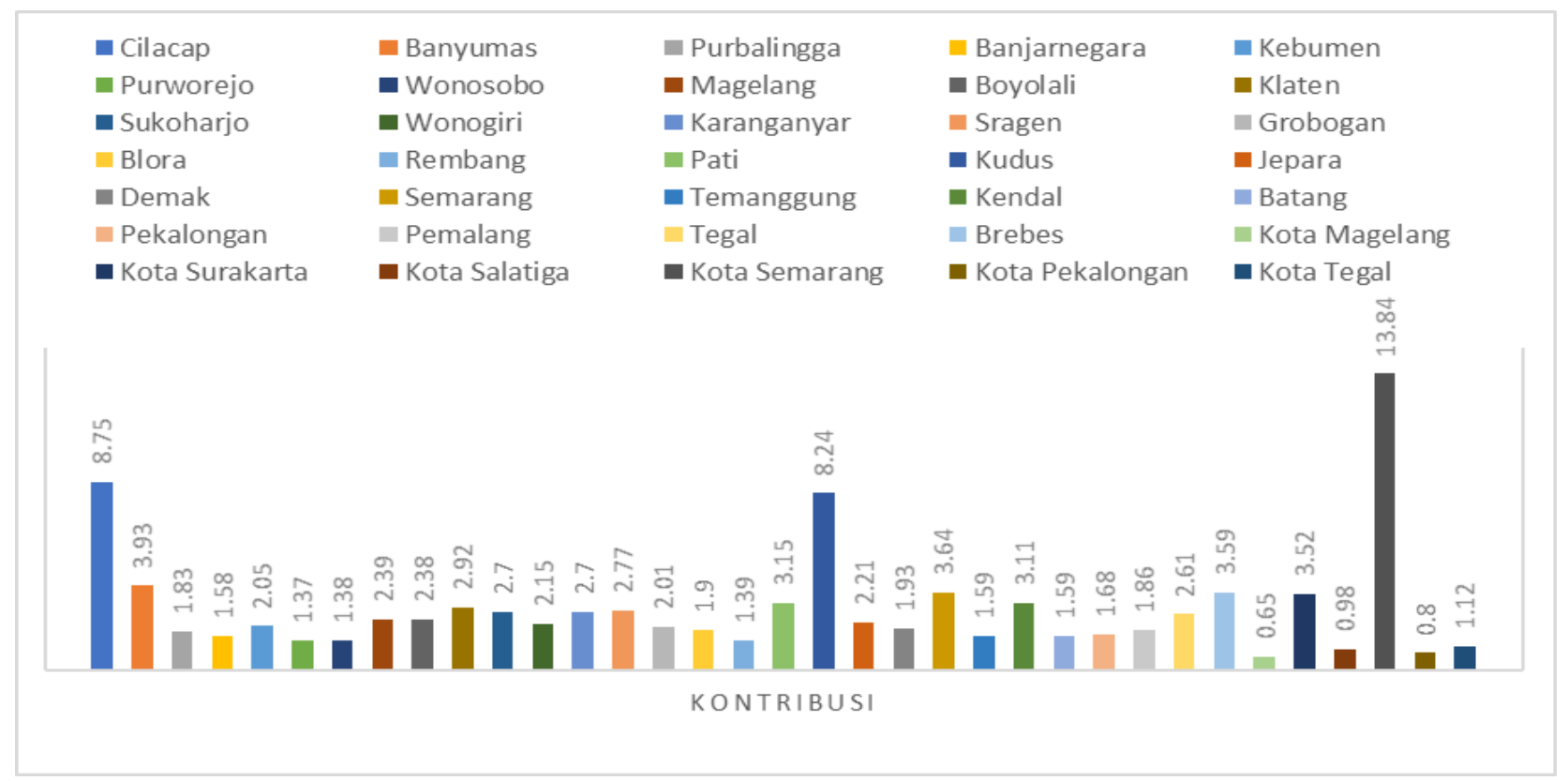

Gambar 1. Kontribusi Sektor Ekonomi Kabupaten/Kota di Jawa Tengah Tahun 2018

Tidak hanya karakteristik, topografi dan potensi yang berbeda antar daerah, yang mampu mengakibatkan perbedaan pendapatan kabupaten/kota di Jawa Tengah. Disparitas pendapatan berdasarkan hasil riset sebelumnya tercatat dipengaruhi oleh beberapa variabel. Penelitian yang dilakukan oleh Khoirudin \& Musta'in (2020) mendapatkan bahwa pengangguran terbuka dan upah minimum secara positif dan signifikan berpengaruh sementara pertumbuhan ekonomi dan desentralisasi fiskal tidak memiliki pengaruh bagi disparitas pendapatan. Variabel lain yang terindenfikasi dapat mempengaruhi disparitas adalah jumlah penduduk yang bekerja, investasi dan pertumbuhan ekonomi.

Damanik, Zulgani, \& Rosmeli (2018) menemukan bahwa penduduk yang bekerja secara signifikan memiliki pengaruh bagi disparitas pendapatan namun investasi dan pertumbuhan ekonomi menunjukkan tidak mampu mempengaruhi disparitas pendapatan. Penelitian Arif \& Wicaksani (2017) meneliti variabel yang mempengaruhi adalah IPM, pertumbuhan ekonomi, tenaga kerja dan jumlah penduduk. Namun, disparitas pendapatan hanya dipengaruhi oleh IPM di Jawa Timur. Sektor ekonomi pun tercatat memiliki pengaruh terhadap ketimpangan pendapatan. Sa'diyah \& Irham (2016) menemukan bahwa sektor pertanian memiliki peranan cukup signifikan dalam menurunkan disparitas pendapatan di Papua

Aspek-aspek yang mampu mempengaruhi ketimpangan pendapatan ini perlu dikaji lebih guna memantapkan kebijakan yang perlu diambil oleh pemerintah Jawa Tengah dalam upayanya mengurangi kesenjangan pendapatan. Faktor-faktor yang telah diteliti seperti pertumbuhan ekonomi, investasi, angkatan kerja, pertumbuhan penduduk, dan konstribusi sektor ekonomi akan diuji kembali dengan menggunakan data di Jawa Tengah. Namun, penelitian ini akan menambahkan beberapa variabel lain seperti investasi yang dibagi menjadi PMDN dan PMA serta inflasi sehingga mampu menggambarkan kondisi yang mempengaruhi ketimpangan pendapatan di Jawa Tengah secara lebih mendetail. Berdasarkan permasalahan yang dipaparkan, penelitian ini berusaha menganalisa pengaruh variabel seperti pertumbuhan ekonomi, investasi akan dibagi menjadi PMDN (Penanaman Modal Dalam Negeri) dan PMA (Penanaman Modal Asing), inflasi, angkatan kerja, pertumbuhan penduduk dan kontribusi sektor terhadap disparitas pendapatan di Jawa Tengah pada periode 20142019. Sehingga penelian ini bertujuan untuk menganalisa pengaruh pertumbuhan ekonomi, PMDN, PMA, inflasi, angkatan kerja, pertumbuhan penduduk dan konstribusi sektor bagi disparitas pendapatan di Jawa Tengah dengan periode pengamatan 2014-2019.

\section{Kajian Teori}

Kuznets (1955) dalam Arsyad (2010) memunculkan teori disparitas distribusi pendapatan dengan hipotesisnya yaitu Hipotesis U Terbalik. Teori ini mengungkapkan bahwa awal mula pembangunan ekonomi akan membuat pembagian pendapatan menjadi tidak merata. Namun berjalannya waktu, pembangunan akan sampai pada tingkatan tertentu, dan pendapatan akan terdistribusi dengan sempurna. Kenyataannya ketimpangan menjadi salah satu permasalahan ekonomi yang dialami oleh suatu wilayah. Teori Myrdal yang dikutip Jhingan (1990) dalam (Islami \& SBM, 2018) menegaskan ketimpangan akan semakin besar antar suatu wilayah dikarenakan besarnya dampak balik (backwash effect) seperti perpindahan modal atau investasi dibandingkan dengan dampak sebar (spread effect).

Iswanto (2015) menyatakan ketimpangan ekonomi banyak digunakan sebagai ukuran dari perbedaan pendapatan antar wilayah, antar pendapatan di masyarakat atau pendapatan per kapita rata-rata. Disparitas atau ketimpangan distribusi pendapatan umumnya disebabkan adanya perbedaan produktivitas antar individu/kelompok. Hal ini terjadi karena ada golongan individu/kelompok yang produktivitasnya lebih tinggi dibandingkan dengan 
individu/kelompok lainnya (Nurliana \& Chaira, 2017). lebih kecil dari $\alpha$ maka ada pengaruh antara variabel Pernyataan tersebut dipertegas oleh Rukmana (2012) yang bebas dengan variabel tidak bebas.

menyatakan kesenjangan pendapatan disebabkan oleh apa yang diterima oleh individu sebagai balas jasa tidak merata. Ukuran untuk mengukur disparitas pendapatan adalah Indeks Williamson. Formula untuk menghitung Indeks Williamson (Mahardiki \& Santoso, 2013):

$$
V_{w}=\frac{\sqrt{\sum_{i=1}^{n}\left(Y_{i}-Y\right)^{2}\left(\frac{f_{i}}{n}\right)}}{Y}
$$

$\mathrm{V}_{\mathrm{w}}$ merupakan indeks ketimpangan Williamson, $\mathrm{Y}_{\mathrm{i}}$ merupakan PDRB per kapita kabupaten/kota, Y merupakan PDRB per kapita provinsi, $F_{i}$ merupakan jumlah penduduk kabupaten/kota dan $\mathrm{n}$ adalah jumlah penduduk provinsi. Nilai $\mathrm{V}_{\mathrm{w}}$ mendekati 1 maka ketimpangan terbilang tinggi dan sebaliknya apabila $V_{w}$ mendekati 0 maka ketimpangan masuk rendah.

\section{Metode}

\section{Rancangan atau Desain Penelitian}

Penelitian ini akan menganalisis pengaruh pertumbuhan ekonomi, Penanaman Modal Dalam Negeri, Penanaman Modal Asing, inflasi, angkatan kerja, pertumbuhan penduduk serta kontribusi sektor ke disparitas distribusi pendapatan.

\section{Jenis dan Sumber Data}

Penelitian ini menggunakan data sekunder meliputi pertumbuhan ekonomi, investasi akan dibagi menjadi PMDN (Penanaman Modal Dalam Negeri) dan PMA (Penanaman Modal Asing), inflasi, angkatan kerja, pertumbuhan penduduk dan kontribusi sektor. Aspek variabel ini akan diteliti untuk melihat pengaruhnya bagi distribusi pendapatan yang diwakili oleh Indeks Williamson dengan periode pengamatan dari 2014 sampai 2019. Data-data tersebut didapatkan dari Badan Pusat Statistik (BPS) Provinsi Jawa Tengah.

\section{Metode Analisis Data}

Metode analisis akan dilakukan dengan analisis regresi berganda, uji t dan uji F. Hasil analisis yang dilakukan akan mendapatkan persamaan regresi seperti berikut (Basuki \& Prawoto, 2016):

Keterangan:

$$
Y^{\prime}=a+b_{1} X_{1}+b_{2} X_{2}+\cdots+b_{n} X_{n}
$$

$$
\begin{array}{ll}
\mathrm{Y} & =\text { Variabel dependen } \\
\mathrm{X}_{1}, \mathrm{X}_{2} \text { dan } \mathrm{X}_{\mathrm{n}} & =\text { Variabel independen } \\
\mathrm{a} & =\text { Konstanta } \\
\mathrm{b} & =\text { Koefisien regresi }
\end{array}
$$

Uji $\mathrm{t}$ dan uji $\mathrm{F}$ sebagai alat untuk menguji hipotesis digunakan untuk melihat pengaruh variabel secara parsial maupun secara simultan. Menurut Bagiana, Putra, \& Sunarsih (2016) kriteria penerimaan dan penolakan hipotesis akan membandingkan nilai signifikansi hasil analisis dengan nilai $\alpha(0,05)$. Jika nilai Sig. lebih besar dari $\alpha$ maka tidak terdapat pengaruh antara variabel bebas dengan variabel tidak bebas dan sebaliknya jika nilai Sig.

\section{Hasil dan Pembahasan}

\section{Hasil}

Pendekatan disparitas distribusi pendapatan dalam penelitian ini menggunakan Indeks Williamson (IW). Hasil analisis IW pada kurun waktu 2014-2019 dapat dilihat pada Gambar 2. Berdasarkan hasil olah data maka Kabupaten Kudus dan Kota Semarang memiliki nilai IW masing-masing sebesar 0,374 dan 0,373 sehingga masuk dalam kategori sedang. Hasil analisis juga menunjukkan bahwa wilayah lain dikarenakan memiliki rata-rata IW dibawah 0,3 maka dikategorikan dalam daerah dengan disparitas rendah.

Analisi regresi yang didapatkan berdasarkan perhitungan variabel pertumbuhan ekonomi (LPE), investasi yang akan dibagi menjadi Penanaman Modal Dalam Negeri (PMDN) dan Penanaman Modal Asing (PMA), inflasi (INF), angkatan kerja (AK), pertumbuhan penduduk (PP) dan kontribusi sektor (KS) terhadap disparitas pendapatan didapatkan bahwa persamaan regresi yang dihasilkan sebagai berikut:

$Y^{\prime}=0,045-0,004 L P E-0,139 P M D N-$

$0,045 P M A+0,001 I N F-2,591 A K+1,052 P P+$

$0,033 K S$

Hasil analisis regresi menunjukkan bahwa pertumbuhan ekonomi, Penanaman Modal Dalam Negeri, Penanaman Modal Asing dan angkatan kerja menunjukkan hasil yang negatif. Hal ini menunjukkan variabel tersebut memiliki hubungan negatif dengan ketimpangan distribusi pendapatan. Artinya semakin meningkat variabel LPE, PMDN, PMA, dan AK maka ketimpangan distribusi pendapatan akan menurun. Hasil positif ditunjukkan oleh variabel inflasi dan pertumbuhan penduduk. Penilaian positif ini menunjukkan bahwa apabila terjadi peningkatan INF, PP dan KS maka disparitas pendapatan akan meningkat pula. Hasil regresi tersaji pada Tabel 1.

Pengidentifikasian variabel terpilih untuk analisis $R$ square didapatkan angka 0,752. Artinya LPE, PMDN, PMA, INF, AK, PP dan KS mampu menjelaskan pengaruh sebesar 75,2 persen untuk disparitas pendapatan di Jawa Tengah sementara 24,8 persen dinyatakan oleh aspek di luar variabel penelitian yang tidak diteliti. Untuk lebih jelasnya pada pada Tabel 2 .

Untuk melihat pengaruh antar variabel dapat dilihat pada Tabel 1. Didapatkan bahwa LPE, PMA, INF, AK, dan PP tidak memiliki pengaruh parsial bagi ketimpangan distribusi pendapatan di Jawa Tengah pada periode penelitian. Nilai sig. pada uji t untuk LPE sebesar 0,104, PMA didapatkan nilai sig. uji t sebesar 0,288, untuk INF sebesar 0,573, nilai sig. uji t untuk AK didapatkan 0,154 dan PP sebesar 0,535. Nilai ini menunjukkan bahwa sig. uji t lebih besar dari sig. 0,05 sehingga menunjukkan disparitas pendapatan tidak dipengaruhi oleh LPE, PMA, INF, AK, dan PP. Hasil analisis uji t, menunjukkan bahwa hanya PMDN dan kontribusi sektor (KS) yang terindikasi ada pengaruh terhadap disparitas pendapatan. Hal ini dibuktikan dengan nilai sig. pada uji t untuk PMDN sebesar 0,005 dan KS sebesar 0,000. Nilai sig. uji 
t PMDN dan KS maka nilainya lebih kecil dari 0,05. Jika merujuk pada pengaruh simultan maka LPE, PMDN, PMA, INF, AK dan PP tercatat secara bersama-sama mampu mempengaruhi ketimpangan distribusi pendapatan. Hal ini dinyatakan dalam nilai sig. uji $F$ sebesar 0,000 sehingga nilai ini menjadi lebih kecil dibandingkan nilai sig. 0,05. Hasil uji F dapat dilihat pada tabel 3 .

\section{Pembahasan}

Pertumbuhan ekonomi berdasarkan hasil analisis regresi bernilai negatif terhadap disparitas. Hal ini berarti semakin tinggi pertumbuhan ekonomi maka disparitas pendapatan akan menurun. Sejalan dengan pernyataan Khoirudin \& Musta'in (2020) yang menyatakan peningkatan produksi dapat terjadi karena pertumbuhan ekonomi. Peningkatan produksi akan menambah pendapatan masyarakat dan dampaknya ketimpangan pendapatan masyarakat akan semakin mengecil. Namun, pengaruh pertumbuhan ekonomi pada periode penelitian tidak signifikan. Hal ini menunjukan bahwa naik atau turunnya pertumbuhan ekonomi tidak berdampak pada peningkatan atau penurunan ketimpangan distribusi pendapatan. Tidak signifikannya pertumbuhan ekonomi terhadap distribusi pendapatan di Jawa Tengah dikarenakan pertumbuhan ekonomi yang tidak merata antar kabupaten/kota. Berdasarkan data BPS, pertumbuhan ekonomi didominasi oleh Kota Semarang, kabupaten Cilacap dan Kabupaten Kudus, sehingga ketimpangan menjadi semakin besar antara kabupaten/kota di Jawa Tengah. Hal ini Hasil tidak signifikan juga ditunjukkan oleh penelitian Arif \& Wicaksani (2017) dan Khoirudin \& Musta'in (2020).

Aspek lain yang akan diteliti adalah investasi. Pada penelitian ini, investasi dibagi menjadi PMDN dan PMA. PMDN dan PMA memiliki hubungan negatif dengan disparitas pendapatan masyarakat. Peningkatan investasi baik PMDN dan PMA akan menurunkan disparitas disparitas dan penurunan investasi PMDN dan PMA akan meningkatkan disparitas pendapatan. Secara teori investasi digunakan untuk menggenjot pembangunan dan membuka kesempatan kerja sehingga pendapatan masyarakat akan meningkat yang kemudian akan menurunkan disparitas pendapatan masyarakat (Danawati, Bendesa, \& Utama, 2016). Jika melihat pengaruhnya terhadap disparitas pendapatan, maka didapatkan hanya PMDN yang mampu mempengaruhi disparitas pendapatan sementara PMA tidak mampu mempengaruhi disparitas pendapatan. Hasil penelitian Damanik et al. (2018) menemukan investasi berpengaruh positif terhadap disparitas pendapatan. Namun, investasi tersebut tidak dibagi menjadi investasi PMDN atau PMA. PMDN di Jawa Tengah memiliki dampak yang baik dalam mengurangi disparitas dikarenakan investasi dalam negeri ini merata di seluruh kabupaten/kota Jawa Tengah dalam kurun waktu penelitian.

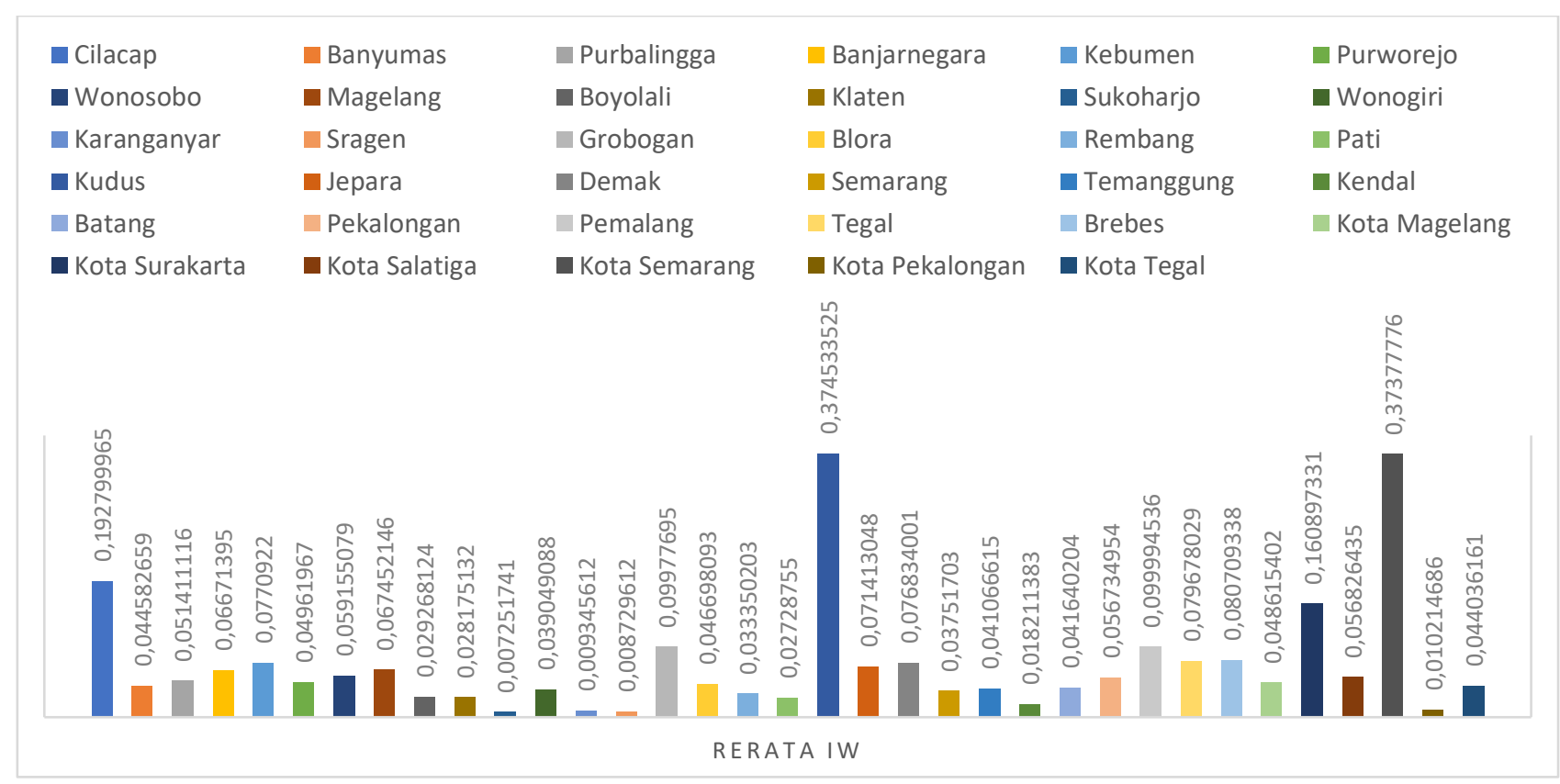

Gambar 2. Rata-Rata Indeks Williamson di Jawa Tengah 2014-2019 
Tabel 1. Output Regresi

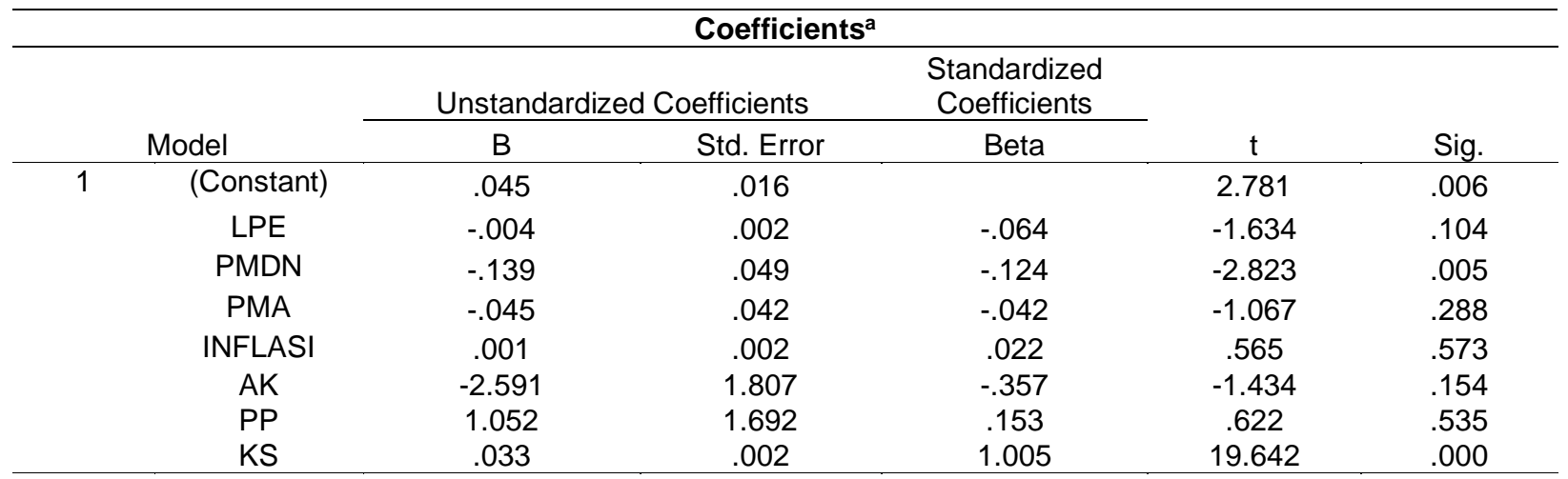

a. Dependent Variable: IW

Sumber : data diolah

Tabel 2. Model Summary

\begin{tabular}{cccccc}
\hline & \multicolumn{5}{c}{ Model Summary $^{\mathbf{b}}$} \\
Model & $\mathrm{R}$ & $\mathrm{R}$ Square & Adjusted R Square & Std. Error of the Estimate & Durbin-Watson \\
\hline 1 & $.867^{\mathrm{a}}$ & .752 & .741 & .04238905 & .433 \\
\hline
\end{tabular}

a. Predictors: (Constant), KS, INFLASI, PMA, LPE, PMDN, PP, AK

b. Dependent Variable: IW

Sumber : data diolah

Tabel 3. ANOVA

\begin{tabular}{|c|c|c|c|c|c|c|}
\hline \multicolumn{7}{|c|}{ ANOVA $^{a}$} \\
\hline & Model & Sum of Squares & df & Mean Square & $\mathrm{F}$ & Sig. \\
\hline \multirow[t]{3}{*}{1} & Regression & .909 & 7 & .130 & 72.277 & $.000^{\mathrm{b}}$ \\
\hline & Residual & .300 & 167 & .002 & & \\
\hline & Total & 1.209 & 174 & & & \\
\hline
\end{tabular}

a. Dependent Variable: IW

b. Predictors: (Constant), KS, INFLASI, PMA, LPE, PMDN, PP, AK

Sumber : data diolah

PMA tidak memiliki pengaruh dikarenakan berdasarkan data BPS tercatat tidak merata di setiap kabupaten/kota Jawa Tengah. Ada kabupaten/kota tidak dimasuki oleh investasi asing pada kurun waktu tertentu. Dengan kata lain, distribusi PMA hanya pada wilayah kabupaten/kota tertentu saja yang dinilai memberikan keuntungan untuk para investor.

Hasil yang didapatkan menunjukan bahwa inflasi tidak berpengaruh terhadap disparitas pendapatan di Jawa Tengah. Artinya, besar kecilnya inflasi dalam periode pengamatan tidak akan berdampak terhadap disparitas pendapatan. Aspek inflasi secara teori memiliki dampak yang tidak merata untuk pendapatan masyarakat. Pada periode penelitian, rata-rata inflasi di Jawa Tengah sebesar 2,90 persen. Inflasi paling kecil pada Kabupaten Karanganyar sebesar 2.49 persen dan inflasi paling tinggi pada Kabupaten Jepara sebesar 3,76 persen. Hal ini menunjukkan tidak meratanya tingkat inflasi antar kabupaten/kota meskipun tingkat inflasi terbilang rendah (dibawah 10 persen). Namun, hal ini berdampak pada peningkatan pengeluaran yang dilakukan oleh masyarakat di Jawa Tengah sementara pendapatan yang diterima tetap. Hal ini yang menjadikan inflasi tidak berdampak pada disparitas pendapatan. Penelitian Pramesti \& Yasa (2019) juga menemukan inflasi tidak berpengaruh terhadap ketimpangan pendapatan.

Jumlah angkatan kerja berdasarkan beberapa penelitian juga mampu mempengaruhi disparitas pendapatan. Penelitian Damanik et al. (2018) menemukan bahwa ketimpangan distribusi secara positif signifikan dapat dipengaruhi oleh angkatan bekerja. Namun, penelitian ini mendapatkan bahwa angkatan kerja tidak mampu memberikan pengaruh terhadap disparitas distribusi pendapatan. Pergeseran disparitas pendapatan tidak akan berdampak jika angkatan kerja mengalami peningkatan atau penurunan. Hal ini terjadi dikarenakan angkatan kerja menurut BPS dibagi menjadi kelompok bekerja dan kelompok menganggur. Meskipun kelompok bekerja di Jawa Tengah selama kurun waktu pengamatan memiliki jumlah yang lebih tinggi dibandingkan yang menganggur namun pendapatan yang diterima oleh kelompok bekerja tidak bisa memberikan efek terhadap pergeseran disparitas pendapatan.

Disparitas pendapatan secara teori bisa diakibatkan oleh pertumbuhan penduduk. Banyaknya penduduk akan berdampak pada pendapatan perkapita. Semakin banyak penduduk maka pendapatan per kapita akan makin menurun. Selanjutkan akan semakin melebarkan disparitas pendapatan (Arsyad, 2010). Namun, hasil yang didapatkan dalam penelitian ini pertumbuhan penduduk didapatkan tiidak bisa mempengaruhi disparitas di Jawa Tengah dalam periode pengamatan. Tidak berpengaruhnya terhadap disparitas pendapatan berdasarkan data BPS dapat diakibatkan oleh pertumbuhan penduduk di Jawa Tengah selama masa pengamatan cenderung memiliki pertumbuhan yang kecil. Pertumbuhan penduduk yang kecil ini hampir tidak berdampak pada penghasilan yang diterima masyarakat 
sehingga tidak menjadi faktor yang mampu mempengaruhi disparitas distribusi pendapatan. Hasil ini berbeda dengan penelitian yang dilakukan oleh Matondang (2018) mampu membuktian disparitas distribusi pendapatan dapat dipengaruhi oleh pertumbuhan penduduk.

Variabel lain yang dianalisis pengaruhnya ke disparitas pendapatan adalah kontribusi sektor. Kontribusi sektor ekonomi merupakan komponen dalam pembentuk PDRB suatu wilayah. Penelitian ini menganalisis bahwa kontribusi sektor memiliki pengaruh terhadap ketimpangan distribusi pendapatan. Berdasarkan nilai koefisiennya pun, kontribusi sektor memiliki nilai positif. Ini diartikan bahwa semakin besar kontribusi sektor maka akan berakibat pada peningkatan disparitas pendapatan selama rasio peningkatan PDRB sektor lebih besar daripada total PDRB selama masa periode pengamatan atau sebaliknya. Hasil ini sejalan dengan temuan Sutiono \& Syafitri (2018) pada kontribusi sektor industri perdagangan terhadap ketimpangan, namun berbeda dengan hasil pada sektor pertanian.

\section{Simpulan dan Implikasi Penelitian}

Analisis terhadap disparitas distribusi pendapatan di Jawa Tengah ini mendapatkan kesimpulan sebagai berikut pertumbuhan ekonomi, PMA, inflasi, angkatan kerja dan pertumbuhan penduduk tidak signifikan mempengaruhi secara parsial disparitas distribusi pendapatan. Namun, PMDN dan kontribusi sektor mampu mempengaruhi secara parsial disparitas distribusi pendapatan di Jawa Tengah pada periode 2014-2019. Jika diuji secara simultan, pertumbuhan ekonomi, PMDN, PMA, inflasi, angkatan kerja, pertumbuhan penduduk dan kontribusi sektor memberikan pengaruh signifikan terhadap disparitas distribusi pendapatan.Temuan pada hasil ini akan memberikan gambaran kepada pemerintah Jawa Tengah dalam memetakan aspek-aspek yang mampu berpengaruh terhadap disparitas distribusi pendapatan sehingga dalam pembuatan kebijakan akan berdampak pada penurunan kesenjangan distribusi pendapatan.

Penelitian ini dapat dikembangkan untuk menganalisis kontribusi sektor secara mendalam dengan membagi sektor primer, sekunder dan tersier yang dapat mempengaruhi disparitas pendapatan. Selain itu, dapat dianalisis pula aspek yang paling besar pengaruhnya terhadap disparitas pendapatan dan juga dapat membandingkan antar kabupaten/kota atau antar provinsi.

\section{Ucapan Terima Kasih}

Penulis menyampaikan terima kasih kepada LPPM Universitas Amikom Purwokerto atas Hibah Amikom dalam skim penelitian yaitu Penelitian Dosen Muda Amikom (PDMA) dan kepada Heni Yulianti atas arahan dalam pencarian data penelitian serta kepada pihak-pihak lain yang membantu dalam proses penelitian.

\section{Referensi}

Aminah, S. (2017). Analisis Disparitas Pendapatan Antar Wilayah Di Provinsi Jambi (Pendekatan Entropy
Theil Indeks). Jurnal Ilmiah Universitas Batanghari Jambi, 17(2), 1-10.

Arif, M., \& Wicaksani, R. A. (2017). Ketimpangan Pendapatan Propinsi Jawa Timur dan Faktor- faktor yang Mempengaruhinya. The 6th University Research Colloquium, 323-328.

Arsyad, L. (2010). Ekonomi Pembangunan. Yogyakarta: UPP STIM YKPN.

Bagiana, I. K., Putra, I. G. C., \& Sunarsih, N. M. (2016). Pengaruh Kinerja Keuangan, Ukuran Perusahaan Dan Investment Opportunity Set Terhadap Kebijakan Dividen. Seminar Nasional, (11), 580591.

Basuki, A. T., \& Prawoto, N. (2016). Analisis Regresi Dalam Penelitian Ekonomi \& Bisnis (Dilengkapi Aplikasi SPSS \& EVIEWS). Jakarta: PT RajaGrafindo Persada.

Damanik, A. M., Zulgani, \& Rosmeli. (2018). Faktorfaktor Yang Mempengaruhi Ketimpangan Pendapatan Melalui Pertumbuhan Ekonomi Di Provinsi Jambi. E-Jurnal Perspektif Ekonomi Dan Pembangunan Daerah, 7(1), 15-25.

Danawati, S., Bendesa, I. K., \& Utama, M. S. (2016). Pengaruh Pengeluaran Pemerintah Dan Investasi Terhadap Kesempatan Kerja, Pertumbuhan Ekonomi Serta Ketimpangan Pendapatan Kabupaten/Kota Di Provinsi Bali. E-Jurnal Ekonomi Dan Bisnis Univeristas Udayana, 5(7), 2123-2160.

Islami, F. S., \& SBM, N. (2018). Faktor-Faktor Mempengaruhi Ketimpangan Wilayah di Provinsi Jawa Timur, Indonesia. Media Ekonomi Dan Manajemen, 33(1), 29-39. https://doi.org/10.24856/mem.v33i1.564

Iswanto, D. (2015). Ketimpangan Pendapatan Antar Kabupaten/Kota dan Pertumbuhan Ekonomi di Propinsi Jawa Timur. Signifikan: Jurnal Ilmu Ekonomi, 4(1), 41-66. https://doi.org/10.15408/sjie.v4i1.2293

Khoirudin, R., \& Musta'in, J. L. (2020). Analisis Determinan Ketimpangan Distribusi Pendapatan di Daerah Istimewa Yogyakarta Periode 2005-2013. Tirtayasa Ekonomika, 15(1), 17-30.

Mahardiki, D., \& Santoso, R. P. (2013). Analisis Perubahan Ketimpangan Pendapatan dan Pertumbuhan Ekonomi Antar Propinsi di Indonesia 2006-2011. JEJAK Journal of Economics and Policy, 6(2), 103-213. https://doi.org/10.15294/jejak.v7i1.3596

Matondang, Z. (2018). Pengaruh Jumlah Penduduk, Jumlah Pengangguran dan Tingkat Pendidikan Terhadap Ketimpangan Pendapatan di Desa Palopat Maria Kecamatan Padangsidimpuan Hutaimbaru. Ihtiyath, 2(2), 255-270.

Nurliana, \& Chaira, T. M. I. (2017). Pengaruh Pertumbuhan Ekonomi Terhadap Distribusi Pendapatan Di Indonesia. Jurnal Samudra Ekonomi, 1(2), 174-182. Retrieved from https://www.google.co.id/url?sa=t\&rct=j\&q=\&esrc $=$ s\&source $=$ web $\& \mathrm{~cd}=8 \& \mathrm{cad}=$ rja $\&$ uact $=8 \& \mathrm{ved}=0 \mathrm{ah}$ UKEwjQncTvn_XTAhXMtY8KHelUB9UQFghP MAc\&url=http $\% 3 \mathrm{~A} \% 2 \mathrm{~F} \% 2 \mathrm{Fjurnalmahasiswa.unes}$ a.ac.id\%2Farticle\%2F5930\%2F53\%2Farticle.pdf\& 
usg=AFQjCNGR21xMVCxikKDxYRSp23sYKBPI Cg\&sig2=rxZR

Permana, R. (2016). Faktor-Faktor Yang Mempengaruhi Tingkat Kemiskinan Di Provinsi Kalimantan Timur. FORUM EKONOMI : Jurnal Ekonomi, Manajemen Dan Akuntansi, 18(2), 111-129.

Pramesti, D. A. D. G., \& Yasa, I. N. M. (2019). Pengaruh Investasi dan Inflasi Terhadap Pertumbuhan Ekonomi dan Ketimpangan Distribusi Pendapatan di Kabupaten Klungkung. E-Jurnal EP Unud, $8(11)$, 2562-2590. https://doi.org/10.11428/jhej1987.42.189

Rukmana, I. (2012). Pengaruh Disparitas Pendapatan, Jumlah Penduduk Dan Inflasi Terhadap Pertumbuhan Ekonomi Di Jawa Tengah Tahun 1984-2009. Economics Development Analysis
Journal,

$1(1)$

$26-34$. https://doi.org/10.15294/edaj.v1i1.323

Sa'diyah, S. H., \& Irham. (2016). Peran Sektor Pertanian dalam Mengurangi Ketimpangan Pendapatan di Wilayah Papua Sebelum dan Sesudah Otonomi Khusus. Agro Ekonomi, 27(1), 1-18. https://doi.org/10.22146/jae.30216

Sutiono, F., \& Syafitri, W. (2018). Belanja Kementerian/Lembaga, Belanja APBD, Konstribusi Sektoral, dan Ketimpangan Pendapatan di Jawa Timur. Indonesia Treasury Review Jurnal Perbendaharaan, Keuangan Negara Dan Kebijakan Publik, 3(3), 186-201. 